\title{
$\mathrm{Cu}$ 가 첨가된 $\mathrm{Zn}-\mathrm{Al}$ 합금에서 일방향응고 및 냉간인발에 따른 기계적 특성 향상
}

\author{
정해창 ${ }^{1} \cdot$ 김민수 $^{1,2} \cdot$ 안지혁 $^{2} \cdot$ 임성환 $^{3} \cdot$ 한승전 $^{2 *} \cdot$ 이재현 $^{1 *} \cdot$ 김광호 $^{4}$ \\ ${ }^{1}$ 창원대학교 신금속재료공학과 \\ ${ }^{2}$ 재료연구소 소재실용화 연구실 \\ ${ }^{3}$ 강원대학교 나노응용공학과 \\ ${ }^{4}$ 부산대학교 재료공학과
}

\section{Enhanced Mechanical Properties by Directional Solidification and Cold Drawing in Cu Added Zn-Al Alloys}

\author{
Hae Chang Jeong', Min Soo Kim ${ }^{1,2}$, Jee Hyuk Ahn², Sung Hwan Lim³, Seung Zeon Han, , \\ Jehyun Lee ${ }^{1, *}$, and Kwang Ho Kim ${ }^{4}$ \\ ${ }^{I}$ Department of Materials Science and Engineering, Changwon National University, Changwon 51140, Republic of \\ Korea \\ ${ }^{2}$ Commercialization Research Division, Korea Institute of Materials Science, Changwon 51508, Republic of Korea \\ ${ }^{3}$ Department of Nano Applied Engineering, Kangwon National University, Chuncheon 24341, Republic of Korea \\ ${ }^{4}$ School of Materials Science and Engineering, Pusan National University, Pusan 46241, Republic of Korea
}

\begin{abstract}
The lamellar structure of two phases, the Zn-rich and Al-rich phases, is formed in a $\mathrm{Zn}-5 \mathrm{wt} \% \mathrm{Al}$ eutectic alloy. In order to study the effect of microstructural changes on the tensile properties of eutectic $\mathrm{Zn}-\mathrm{Al}$ binary alloy, $\mathrm{Zn}-\mathrm{Al}$ and $\mathrm{Zn}-\mathrm{Al}-\mathrm{Cu}$ alloys were directionally solidified at a growth rate of $50 \mu \mathrm{m} / \mathrm{s}$ using a Bridgman-type method. The alloys were successively drawn until reaching area reductions of $50 \%$ and $80 \%$ at room temperature. The tensile strength of the $\mathrm{Zn}-\mathrm{Al}$ alloy decreased with increasing drawing ratio. In the $\mathrm{Zn}-\mathrm{Al}-\mathrm{Cu}$ alloy, the tensile strength increased until the area reduction reached $50 \%$, but decreased at an area reduction of $80 \%$. The ductility of alloys prepared by directional solidification increased with increasing drawing ratio. The orientations of the lamellar structure and grains were aligned in the drawn direction. The inter-lamellar distance of the alloys also decreased with increasing drawing ratio. As a result, the trade-off between strength and ductility could be significantly reduced. The strength and ductility combination of $246 \mathrm{MPa}-40 \%$ was achieved by cold drawing with $80 \%$ area reduction of the $\mathrm{Zn}-\mathrm{Al}-\mathrm{Cu}$ alloy.
\end{abstract}

(Received January 10, 2017; Accepted March 27, 2017)

Keywords: eutectic, $\mathrm{Zn}-\mathrm{Al}$ alloy, directional solidification, high strength, high ductility

\section{1. 서 론}

아연합금은 낮은 융점, 우수한 가공성 그리고 상대적으로 낮은 가격으로 인해 전자, 전기, 운송 및 건설산업 등에 구조 재료로써 널리 사용되고 있다. 그러나 아연합금은 앞서 언급 한 낮은 융점과 육방 밀집구조(hexagonal closed packing, $\mathrm{HCP})$ 구조를 가짐으로써 알루미늄, 마그네슘 및 구리합금 등 다른 구조재료에 비해 상대적으로 인장강도가 낮고 취성

*Corresponding Author: Seung Zeon Han, Jehyun Lee [Tel: +82-55-280-3331, E-Mail: szhan@kims.re.kr] [Tel: +82-55-213-3695, E-Mail: ljh@changwon.ac.kr] Copyright (c) The Korean Institute of Metals and Materials
파괴가 용이하게 일어나기 때문에 용도가 제한될 수 밖에 없 다 [1-5]. 따라서 아연 합금의 결정립 미세화[6-10], 석출[11] 및 분산강화[12] 그리고 강소성 가공 $[13,14]$ 등 여러 강화기 구를 이용한 기계적 특성 향상이 연구 중이며, 그 중에서도 $\mathrm{Al}, \mathrm{Mg}, \mathrm{Ti}$ 등의 원소들을 첨가하여 결정립 미세화에 의한 기 계적 특성향상 연구가 많이 진행되고 있다 [2]. 특히 알루미 늄이 아연에 첨가되면 공정(eutectic), 공석(eutectoid)과 편석 (monotectoid) 조직을 형성시켜 기계적 특성과 마찰특성이 향상된다고 알려져 있어서[15], 다상 $\mathrm{Zn}-\mathrm{Al}$ 합금은 이미 상용 합금으로 사용되고 있다. 일반적으로 상용되는 $\mathrm{Zn}-\mathrm{Al}$ 합금은 ZA-8, ZA-12, ZA-27, ZAMAK 등으로 ASTM(American 


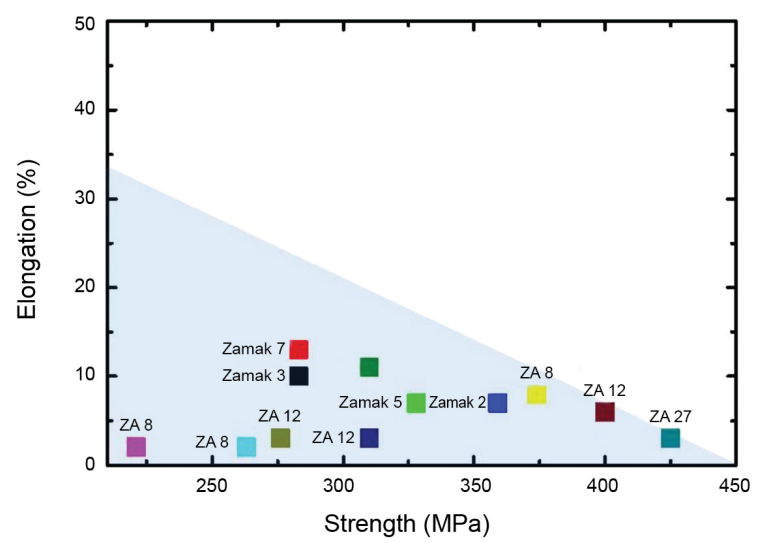

Fig. 1. Tensile strength relation of conventional $\mathrm{Zn}$ alloys [16].

Society for Testing Materials) 규격에 등재되어 있다. 이 합금 들의 인장강도와 연성을 그림 1에 나타내었다 [16]. 그림 1에 서 나타내었듯이, $\mathrm{Zn}-\mathrm{Al}$ 상용합금은 여타 금속 재료와 동일 하게 합금의 인장강도가 증가할 경우, 연성은 필연적으로 감 소하는 상반특성(trade-off property)을 가진다 [17]. 합금에 있어서 연성은 원하는 형태로 용이하게 가공시키는 소성변 형의 중요한 척도가 되고, 또한 강도와 더불어 인성의 크기를 나타내는 인자이므로 합금의 내구성을 증가시키기 위해서는 강도뿐만 아니라 연성도 동시에 증가시켜야 한다. $\mathrm{Zn}-\mathrm{Al}$ 합 금이 고성형성 및 고내구성을 가지기 위해서는 서로 상반특 성이라 할 수 있는 고강도 및 고연성을 동시에 달성해야 한다 $[18,19]$.

그림 2는 $\mathrm{Zn}-\mathrm{Al}$ 합금의 이원계 상태도이다 [20]. 상업용으 로 사용되는 $\mathrm{Zn}-\mathrm{Al}$ 합금은 $\mathrm{Zn}$ 에 $5 \mathrm{wt} \% \mathrm{Al}$ 이 함유된 합금이 주로 사용된다. $5 \mathrm{wt} \%$ 의 $\mathrm{Al}$ 첨가(그림 2의 점선)에서는 냉각 과정중 $381{ }^{\circ} \mathrm{C}$ 에서 미량의 초정 $\eta$ 상과 공정 $\alpha^{\prime}+\eta$ 이 형성되 고, 연속해서 냉각 시 $277^{\circ} \mathrm{C}$ 에서 $\alpha^{\prime}$ 상으로부터 공석 변태가 예상된다. 공정합금은 서로 다른 두 상이 교대로 반복되는 층 상구조(lamellar structure)를 가져, 다른 조성의 합금에 비해 연성은 높지만 인장강도는 낮은 단점을 가진다 [21].

층상구조를 가진 합금 특유의 장점을 유지한 채로 기계적 특성을 향상시키고자 하는 연구가 다양한 합금에서 시도되 고 있다. 철계 합금에서는 압연을 통해 층상구조를 가진 펄라 이트(pearlite) 내부의 세멘타이트(cementite) 상의 두께 및 상 간 거리를 감소시켜 강도를 증가시킬 수 있음이 보고되었고 [21], $\mathrm{Pb}-\mathrm{Cd}, \mathrm{Sn}-\mathrm{Zn}$ 그리고 $\mathrm{Bi}-\mathrm{Cd}$ 등의 공정합금에서 층상구 조를 가진 상들의 두께 및 간격이 감소할 경우 경도가 증가한 다는 것이 보고되었다 [25]. 또한, 냉각 시 생성되는 공정상과 달리, 시효 시 생성되는 층상구조인 불연속 석출물에서도 층

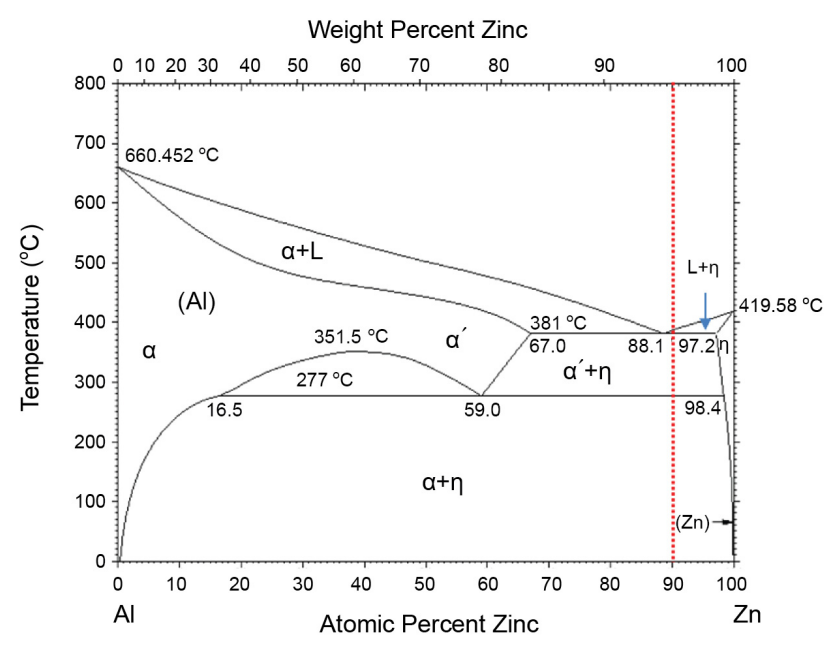

Fig. 2. Al-Zn binary phase and designed composition [20].

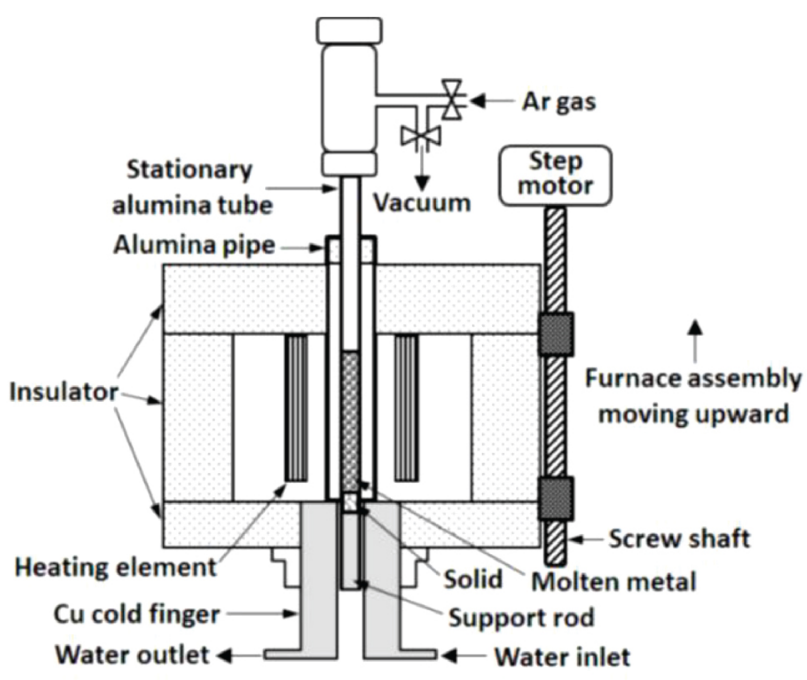

Fig. 3. Schematic drawing showing the modified Bridgman furnace [26].

상간격이 감소할 경우, 기계적 특성이 증가되는 것이 보고된 바 있다 [24,25]. 그러므로 본 연구의 $\mathrm{Zn}-\mathrm{Al}$ 합금 역시 공정조 직을 가지므로, 공정상의 두께 그리고 상간의 간격을 감소시 킬 경우, 기계적 강도의 증가가 예측된다.

공정상들의 두께 및 간격을 변화, 특히 이를 감소시키기 위 하여, 본 연구에서는 두 가지 착안점을 제안하였다. 첫 번째 는 일방향 응고이다. 일반적으로 기계적 특성의 향상의 관점 에서, 일방향 응고된 금속은 응력 방향에 수직인 결정입계가 제거됨으로써, 균열의 시발점을 제거하여 기계적 특성이나 재료의 수명을 향상시키기 위한 공정방안이라 할 수 있다. 또 한 공정합금을 일방향 응고를 통해 재용해할 경우, 응고속도 
Table 1. Nominal and EDS analyzed compositions.

\begin{tabular}{c|c|c|c|c}
\hline \multirow{2}{*}{ Alloy/Analysis } & \multicolumn{3}{|c}{ Composition (wt\%) } \\
\cline { 2 - 5 } & $\mathrm{Zn}$ & $\mathrm{Al}$ & $\mathrm{Cu}$ \\
\hline \multirow{2}{*}{ Alloy 1 } & Nominal & 95 & 5 & \\
\cline { 2 - 5 } & EDS & 92.81 & 7.19 & \\
\hline \multirow{2}{*}{ Alloy 2 } & Nominal & 93 & 5 & 2 \\
\cline { 2 - 5 } & EDS & 89.91 & 7.60 & 2.49 \\
\hline
\end{tabular}

와 온도구배에 의해 층상구조의 두께 및 간격이 줄어든다는 연구도 보고된 바 있다 $[23,27,28]$. 다음 그림 3에 일방향응고 의 모식도를 나타내었다 [26]. 두 번째는 인발공정의 도입이 다. 본 연구의 $\mathrm{Zn}-\mathrm{Al}$ 공정합금을 제조 후 냉간인발하여 공정 조직의 층상간격을 변화시키고자 하였다.

본 연구는 공정 $\mathrm{Zn}-\mathrm{Al}$ 합금의 기계적 특성을 향상시키고 자 일방향응고와 냉간 소성가공을 수행하였으며, 아울러, 공 정조직 이외의 미세조직 형성을 위해 미량의 $\mathrm{Cu}$ 를 첨가하였 다. 공정 $\mathrm{Zn}-\mathrm{Al}$ 합금의 기계적 성질에 미치는 미세조직, 즉 일방향응고, 냉간인발에 의한 미세조직 변화 그리고 미량의 $\mathrm{Cu}$ 첨가가 미세조직 변화에 미치는 영향을 살펴보았고, 미세 조직 변화와 기계적 특성의 상관관계를 비교 분석하였다.

\section{2. 실험 방법}

본 연구에서는 그림 2에 나타낸 공정 및 공석조직을 형성 하리라 예측되는 $\mathrm{Zn}-5 \mathrm{wt} \% \mathrm{Al}$ 합금(그림 2의 빨간색 점선)과 이 합금에 구리를 첨가한 $\mathrm{Zn}-5 \mathrm{wt} \% \mathrm{Al}-2 \mathrm{wt} \% \mathrm{Cu}$ 합금을 순 도 $99.9 \%$ 의 $\mathrm{Zn}, \mathrm{Al}$ 그리고 $\mathrm{Cu}$ 를 사용하여 고주파, 유도 용해 로를 이용하여 주조하였고(표 1), 주조된 잉곳을 $\Phi 4.7 \mathrm{~mm}$ 의 봉재로 절삭 가공하였다.

가공된 봉재 시편은 바로 인발가공되거나 일방향 응고 시 편 제작에 사용되었다. 일방향 응고는 개량형 Bridgman 방식 으로 수행되었다. 봉상으로 절삭 가공된 시편을 $8 \mathrm{~mm} \times 5$ $\mathrm{mm} \times 700 \mathrm{~mm}($ 외경 $\times$ 내경 $\times$ 길이 $)$ 크기의 알루미나 튜브에 장입하여 로 상부에 고정시킨 후 산화를 방지하기 위하여 $\mathrm{Ar}$ 분위기하에서 방향성 응고를 수행하였으며, 용탕온도를 500 ${ }^{\circ} \mathrm{C}$ 로 유지하여 $50 \mu \mathrm{m} / \mathrm{s}$ 의 응고 속도로 성장시킨 후 장비 하 단에 위치한 수조에 급랭시켰다. 그 후 일반주조시편과 일방 향응고 시편을 상온 인발 가공으로 단면적 감소율 $50 \%, 80 \%$ 로 가공하였다.

고상 및 액상선 온도를 알기 위해서 시차 열분석 (differential scanning calorimetry, DSC, NETZSCH model: DSC 404C Pegasus)법을 사용하였고 이때 승온 및 냉각속도
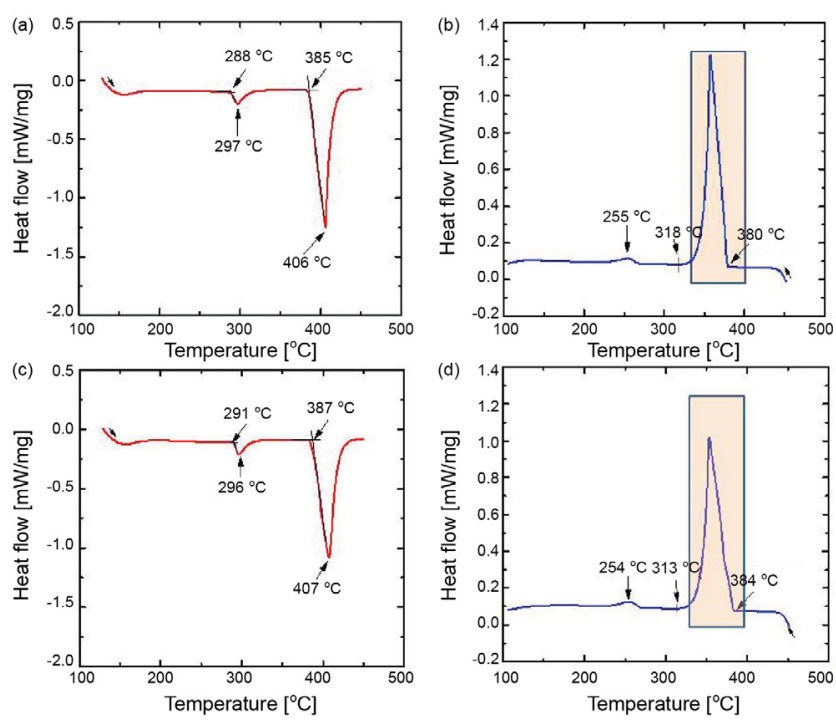

Fig. 4. Results of DSC: (a,b) alloy 1, (c,d) alloy 2, (a,c) heating, and $(b, d)$ cooling.

는 $10 \mathrm{~K} / \mathrm{min}$ 로 설정하였다.

인발 가공된 모든 시편들을 길이방향으로 연마한 후 $5 \%$ $\mathrm{HCl}+95 \%$ methanol 용액으로 에칭하였고, 미세구조 관측 을 위해 광학현미경(optical microscope, OM, OLYMPUS, GX51), 주사전자현미경(scanning electron microscope, SEM, JEOL, JSM-6510), 투과전자현미경(transmission electron microscope, TEM, JEOL, JEOL-2100F)을 이용하였으며, 에 너지분광분석(energy dispersive X-ray spectroscopy, EDS)을 통해 합금의 성분을 분석하였다.

인장시편은 ASTM E8M 규격으로 가공하였고, Shimadzu 사의 EZ-L을 사용하여 $12.5 \mathrm{~mm}$ 신율계로 $2 \mathrm{~mm} / \mathrm{min}$ 의 속도 로 인장시험하였다. 경도는 미소경도계(micro-Vicker's hardness, Matsuzawa, model: MX70)를 이용하여 하중 $0.1 \mathrm{kgf}$ 으로 측 정하였고, $\mathrm{Zn}-\mathrm{Al}$ 합금의 공정상 간격은 image tool (UTHSCSA, ver.3.0)을 이용하여 측정하였다.

\section{3. 결 과}

\subsection{DSC 분석}

대기유도용해로로 제조된 각 합금의 DSC 분석 결과를 그 림 4에 나타내었다. 그림 4의 승온곡선은 (a)와 (c)에, 냉각곡 선은 (b)와 (d)에 각각 나타내었으며, 합금 별로, alloy 1 과 2 의 냉각곡선 과 승온곡선은 각각 (a), (b) 그리고 (c), (d)에 나 타내었다. 승온곡선에서 나타난 액상선 온도 $\left(\mathrm{T}_{\mathrm{L}}\right)$ 는 alloy 1 및 2에서 각각 $406{ }^{\circ} \mathrm{C}$ 와 $407{ }^{\circ} \mathrm{C}$ 로 나타났고, 고상선 온도 $\left(\mathrm{T}_{\mathrm{S}}\right)$ 
Table 2. Estimation of solidus and liquidus temperature in the alloys by DSC.

\begin{tabular}{l|c|c|c|c|c}
\hline & \multicolumn{5}{|c}{ Temperature } \\
\cline { 2 - 6 } & Liquidus & $\begin{array}{c}\text { Primary } \eta \\
\text { phase }\end{array}$ & $\begin{array}{c}\text { Eutectic } \\
\text { starting }\end{array}$ & $\begin{array}{c}\text { Eutectic } \\
\text { end }\end{array}$ & Eutectoid \\
\hline Alloy1 & $406^{\circ} \mathrm{C}$ & $380{ }^{\circ} \mathrm{C}$ & $377^{\circ} \mathrm{C}$ & $318^{\circ} \mathrm{C}$ & $255^{\circ} \mathrm{C}$ \\
\hline Alloy2 & $407{ }^{\circ} \mathrm{C}$ & $384{ }^{\circ} \mathrm{C}$ & $371.5^{\circ} \mathrm{C}$ & $313^{\circ} \mathrm{C}$ & $254^{\circ} \mathrm{C}$ \\
\hline
\end{tabular}

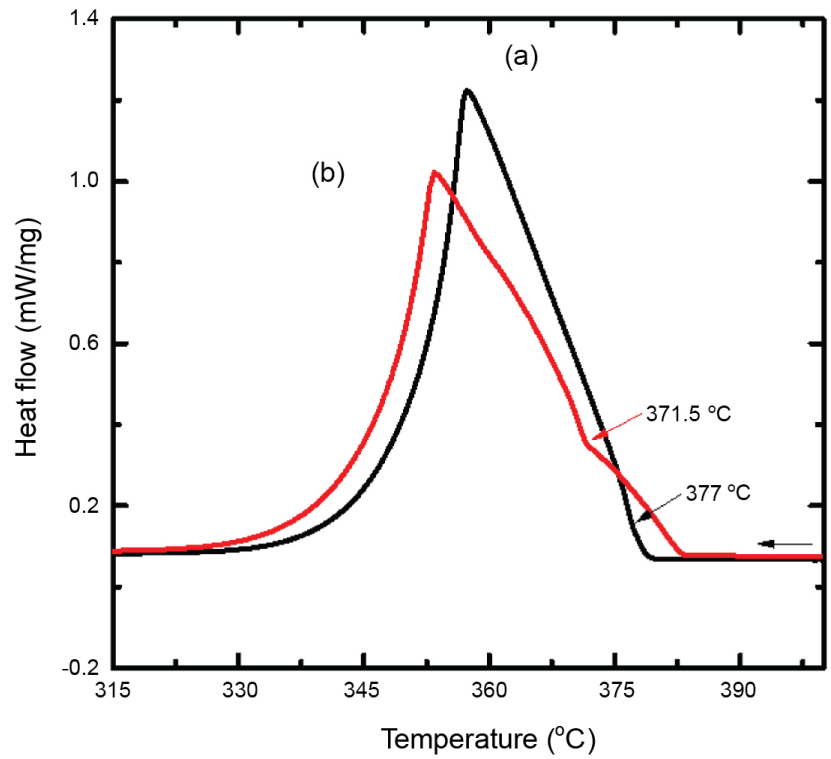

Fig. 5. A comparison of the cooling graph at marked rectangle of Fig. 4. (a) alloy1 and (b) alloy 2.

는 $385{ }^{\circ} \mathrm{C}$ 와 $387{ }^{\circ} \mathrm{C}$ 로 각각 나타났다. 그리고 냉각곡선에서 alloy 1 과 2 의 공정온도 $\left(\mathrm{T}_{\mathrm{E}}\right)$ 는 $377{ }^{\circ} \mathrm{C}$ 와 $371.5{ }^{\circ} \mathrm{C}$ 로 나타났고 이를 표 2에 정리하였다. 그림 5 는 그림 $4(\mathrm{~b}, \mathrm{~d})$ 냉각곡선의 초 기 변곡점의(네모 안) 확대 그래프에서 알 수 있듯이 $\mathrm{Cu}$ 의 첨 가에 의해 변곡점이 생성되었고, 이는 $\mathrm{Cu}$ 를 첨가함으로써 alloy 2에서 alloy 1 보다 $\eta$ 초정상이 다소 많이 먼저 생성되었 음을 확인하는 결과라고 할 수 있다.

\section{2. 미세조직 분석}

각 합금에서 일방향응고 수행 유무에 따른 미세조직 변화 를 그림 6에 나타내었다. 그림 6(a,b)는 alloy 1과 2의 일반주 조 시편의 미세조직을 나타내었고, 그림 $6(\mathrm{c}, \mathrm{d})$ 는 alloy 1 과 2 의 일방향응고된 시편의 미세조직을 나타내었다. 미세조직 상에서 화살표는 $\eta$ 초정상을 나타내었으며, 그림 6(c)의 하얀 색 화살표는 alloy 1 과 2의 일방향 응고 방향을 나타내었다. Alloy 1과 2의 미세조직 변화, 즉 $\mathrm{Cu}$ 첨가에 의한 미세조직 변화는 합금에 $\mathrm{Cu}$ 가 첨가됨에 따라, 초정상이 비교적 크고
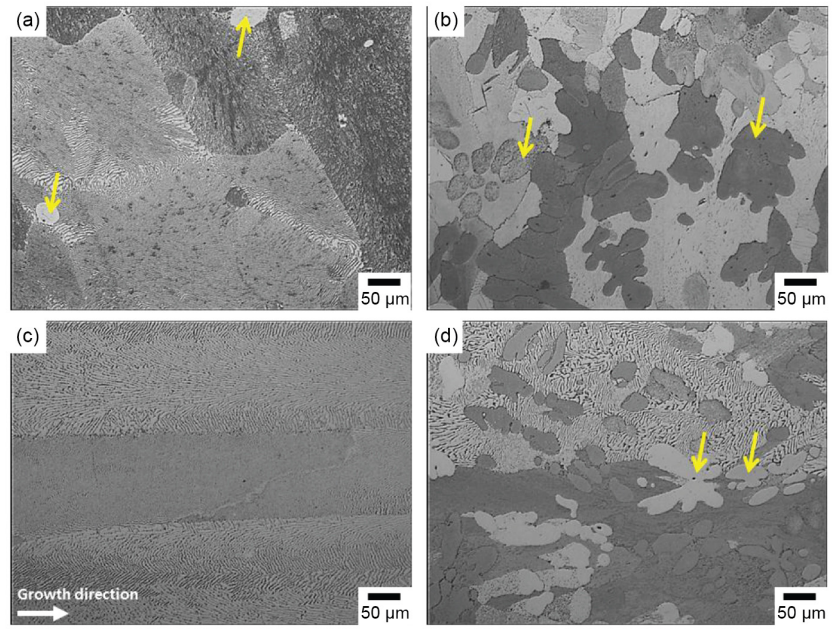

Fig. 6. Optical images of $\mathrm{Zn}-\mathrm{Al}$ alloys. (a) Alloy 1 and (b) alloy 2 are fabricated by conventionally cast. (c) Alloy 1 and (d) alloy 2 are fabricated by directionally solidified. Arrows indicate the $\eta$ primary phase.

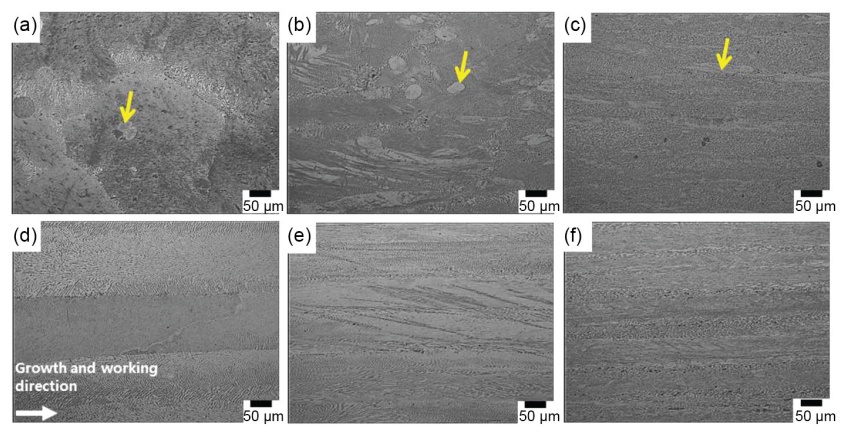

Fig. 7. Optical images of alloy 1. (a) (c) are fabricated by conventionally cast and (d) (f) are fabricated by directionally solidified. (a,d) are as-cast, $(\mathrm{b}, \mathrm{e})$ are drawn by $50 \%$ reduction, and $(\mathrm{c}, \mathrm{f})$ are drawn by $80 \%$ reduction. Arrows indicate the $\eta$ primary phase.

많이 생성되었다는 것이다. 그리고 일방향 응고의 수행유무 에 따른 미세조직 차이로는 일방향 응고 후 합금에 상관없이, 일반주조 시편에 비해 결정립이 일방향으로 배향되었다는 것이다. 따라서, $\mathrm{Cu}$ 를 첨가한 alloy 2 를 일방향 응고할 경우, 배향된 결정립과 초정상이 동시에 생성된 미세조직이 구현 되었다(그림 6(d)). 그리고 모든 합금에서 응고방법에 상관없 이 기지조직(초정외의 조직)에서는 공정구조, 즉 층상구조의 미세조직이 관찰되었다. 이는 어떠한 응고방법에서도 공통 적으로 생성된 구조라고 할 수 있다.

일반주조 및 일방향응고된 alloy 1 과 2를 상온에서 인발을 수행하였고, 그 미세조직을 각각 그림 7,8에 나타내었다. Alloy 1 의 일반주조시편과 인발후의 미세조직을 그림 7(a-c) 

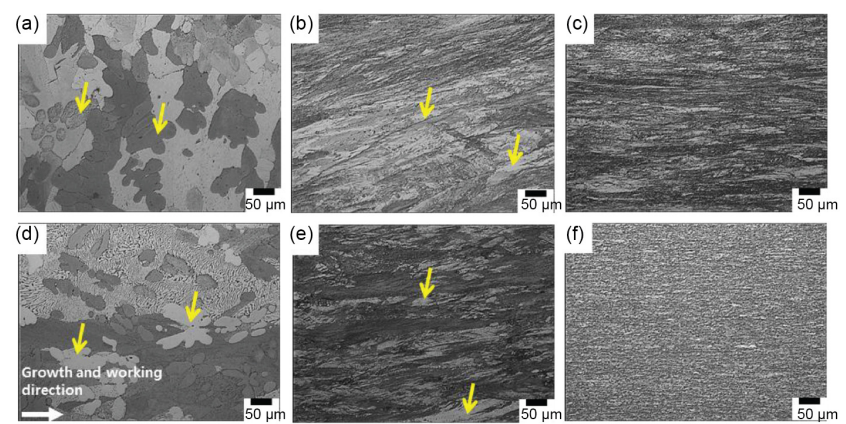

Fig. 8. Optical images of alloy 2. (a) (c) are fabricated by conventional cast, and $(\mathrm{d}, \mathrm{f})$ are fabricated by directional solidified. (a,d) are as-cast, (b,e) are drawn by $50 \%$ reduction, and $(\mathrm{c}, \mathrm{f})$ are drawn by $80 \%$ reduction. Arrows indicate the $\eta$ primary phase.
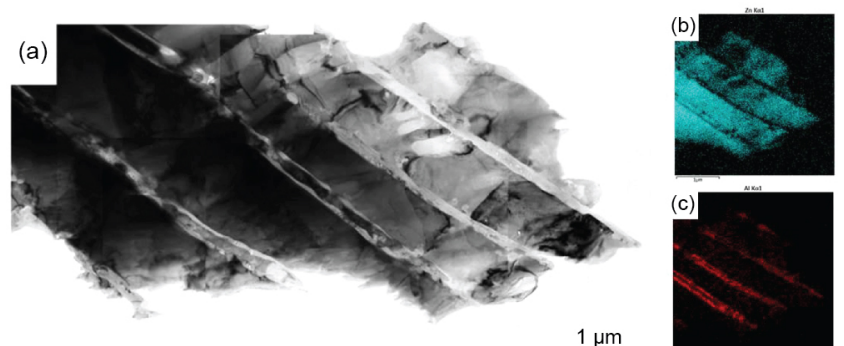

$1 \mu \mathrm{m}$

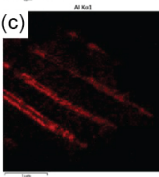

Fig. 9. (a) TEM images of 50\% drawn alloy 1 after directional solidification. Composition analysis results of (b) $\mathrm{Zn}$ and (c) $\mathrm{Al}$ by EDS.

에 그리고 일방향 응고시편과 인발후의 미세조직 결과를 (d-f)에 나타내었다. 미세조직 상의 노란색 화살표는 초정상 을 나타내었다. 일반주조시편은 결정립 크기가 크고 초정이 존재하였지만 일방향응고된 시편에서는 초정이 관찰되지 않 았으며, 결정립이 일방향으로 정렬된 것을 확인하였다. $\mathrm{Cu}$ 를 첨가한 alloy 2 의 일반주조시편과 인발후의 미세조직을 그림 8(a-c)에, 그리고 일방향 응고시편과 인발후의 미세조직 결과 를 그림 8(d-f)에 나타내었다. 일반주조된 시편에서는 초정이 $\mathrm{Cu}$ 를 첨가하지 않은 합금에 비해 대량으로 생성 된 것을 확 인하였고, 일방향응고를 하였을 때, 일방향으로 정렬된 결정 립과 초정상을 동시에 확인할 수 있었다. 그리고 상온인발시, 기지상과 초정이 모두 인발 방향으로 정렬되었음을 확인하 였다.

$\mathrm{OM}$ 으로 관찰된 공정조직(층상구조)이 상온 인발시 어떠 한 변화를 보이는지 관찰하기 위하여 alloy 1 을 단면적 감소 율 $50 \%$ 로 상온 인발하여 미세조직을 TEM으로 관찰한 결과 를 그림 9에 나타내었다. 그림 9(a)는 50\% 인발가공된 시편 의 TEM 결과이고 그림 9(b)는 그림 9(a)에 나타낸 공정조직
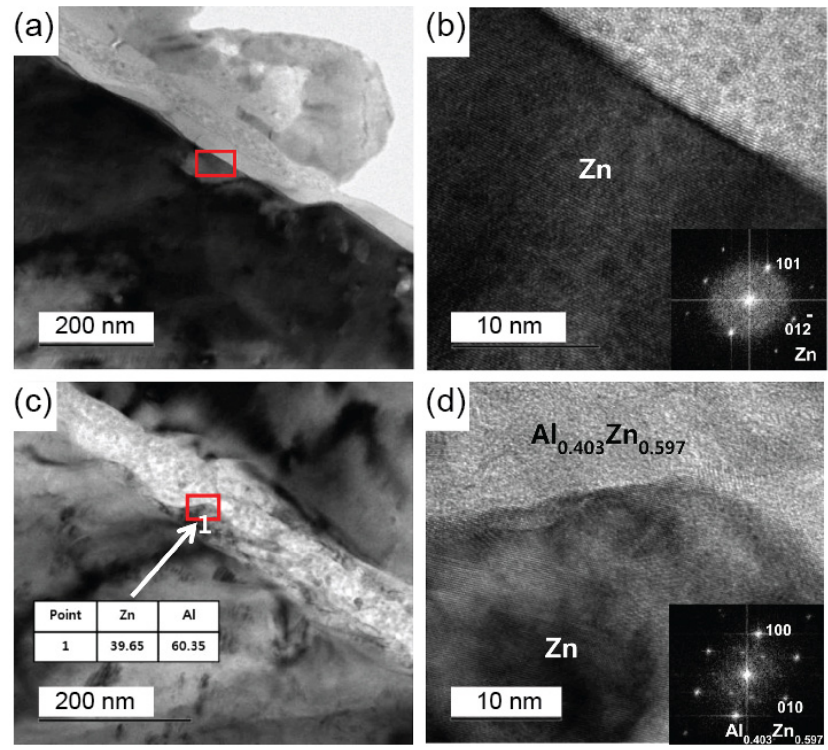

Fig. 10. TEM images of $50 \%$ drawn alloy 1 after directional solidification: $(b, d)$ : high solution TEM image at red rectangle of $(\mathrm{a}, \mathrm{c})$ and SADPS.

의 $\mathrm{Zn}$ 와 $\mathrm{Al}$ 의 $\mathrm{EDS}$ 맵핑(mapping) 결과를 나타내었다. 그림 9(b)의 결과, 공정조직의 큰 부피를 차지하는 기지부분은 $\mathrm{Zn}$ 이며, 층상구조를 가지는 상은 $\mathrm{Al}$ 을 높게 함유하는 결과를 나 타내었다. 이는 그림 2의 상태도와 일치하는 것을 알 수 있다. 그림 10 에 일방향 응고 후 $50 \%$ 상온인발된 alloy 1 의 TEM 사진과 $\mathrm{EDS}$ 분석 결과를 나타냈다. 생성된 층상구조 즉 $\mathrm{Zn}$ rich 및 $\mathrm{Al}$ rich영역을 $\mathrm{EDS}$ 분석을 수행한 결과, $\mathrm{Al}$ rich 영역 의 조성은 그림 $10(\mathrm{c})$ 에서 나타낸 바와 같이 $\mathrm{Zn}$ 이 약 $40 \%$ 그 리고 나머지가 $\mathrm{Al}$ 으로 구성되어 있음을 확인하였고 이는 그 림 2의 상태도에서 나타낸 조성과 거의 일치하는 것을 알 수 있었다. 그리고 그림 $10(\mathrm{~b}, \mathrm{~d})$ 의 $\mathrm{Al}$ 및 $\mathrm{Zn}$ rich상간계면을 TEM 회절 분석(selected area diffraction pattern, SADP)으로 분석한 결과, 두 상간의 계면은 정합성을 지니지 않는 것으로 분석되었다.

\section{3. 기계적 성질}

상온 인발가공 후 $\mathrm{Zn}-\mathrm{Al}$ 합금의 성장 및 가공방향에 따른 경도변화를 그림 11 에 인발에 따른 단면적 감소율변화로 나 타내었다. 그 결과 실험된 모든 합금에서 경도는 단면적 감소 율이 증가할수록, 즉 인발율이 증가할 수록 감소하는 경향을 보였다. 그런데, $\mathrm{Cu}$ 를 첨가한 $\mathrm{Zn}-\mathrm{Al}$ 합금은 모든 인발조건에 서 $\mathrm{Cu}$ 를 첨가하지 않은 시편에 비해 경도가 높은 값을 가짐 을 알 수 있었다. 


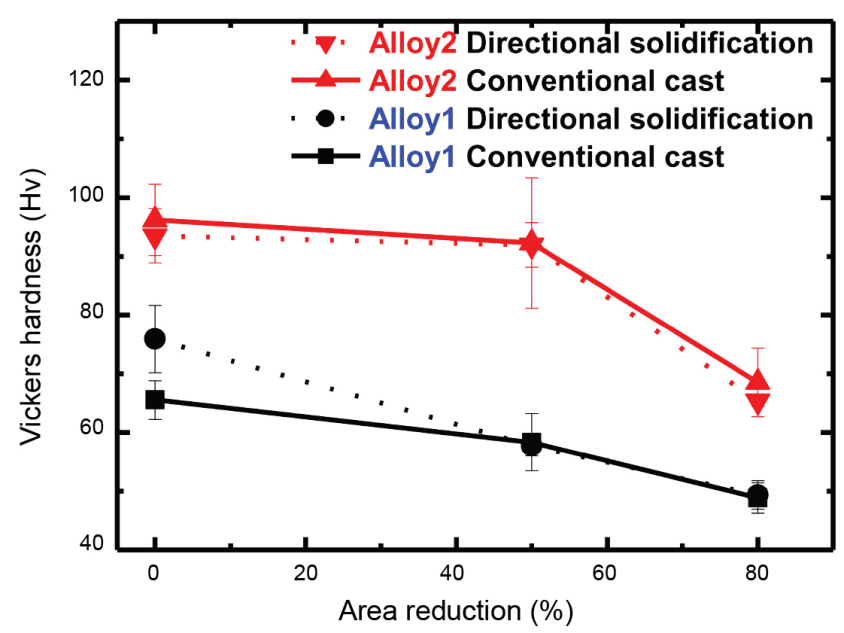

Fig. 11. Hardness change with increasing area reduction of $\mathrm{Zn}-\mathrm{Al}$ alloys.
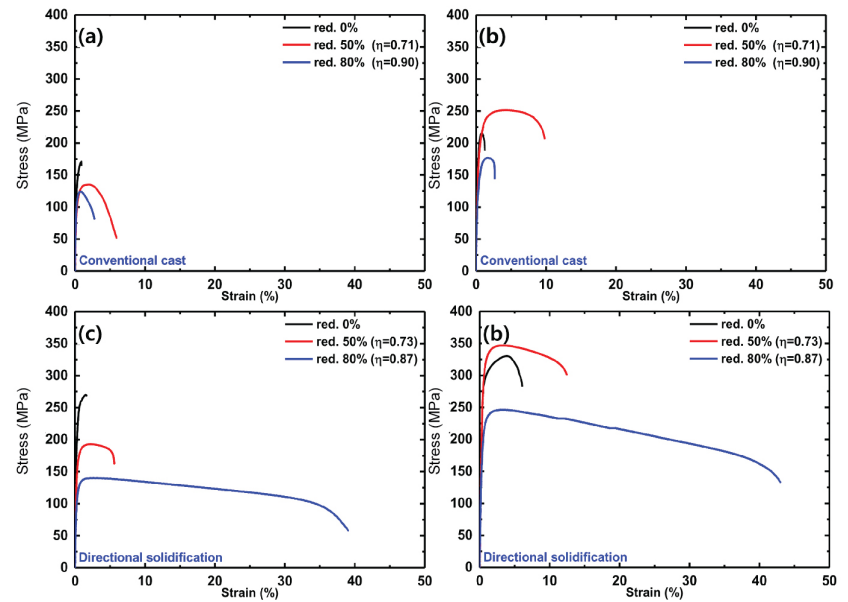

Fig. 12. Stress-strain curves of $\mathrm{Zn}-\mathrm{Al}$ alloys. (a) Alloy 1 and (b) alloy 2 are fabricated by conventional cast. (c) Alloy 1 and (d) alloy 2 are fabricated by directional solidification.

$\mathrm{Zn}-\mathrm{Al}$ 합금에서 $\mathrm{Cu}$ 첨가 유무, 일방향 응고 유무와 인발시 단면적 감소율에 따른 인장시험 결과를 그림 12에 나타내었 다. 그림 12(a,c)는 alloy 1 , 그림 12(b,d)는 alloy 2이다. 일반 주조된 alloy 1 의 경우, 인발가공율이 증가할수록 인장강도 가 감소하였고, $\mathrm{Cu}$ 가 첨가된 alloy 2는 단면적 감소율 $50 \%$ 인발 까지는 인장강도가 증가하다가 단면적 감소율 $80 \%$ 에 서 인장강도가 감소하는 것을 보였다. 그러나 일방향 응고된 alloy 1 과 2는 인장강도의 변화는 일반주조된 시편과 동일한 양상을 보였지만 특이하게, $80 \%$ 인발가공시 두 합금 모두 연 신율이 매우 증가하는 것을 보였다. $\mathrm{Cu}$ 가 첨가된 합금의 경 우는 $80 \%$ 인발후, 인장강도 $250 \mathrm{MPa}$ 그리고 거의 $44 \%$ 의 연 신율을 나타낸 것을 확인하였다. 즉 공정조성의 $\mathrm{Zn}-5 \mathrm{wt} \% \mathrm{Al}$
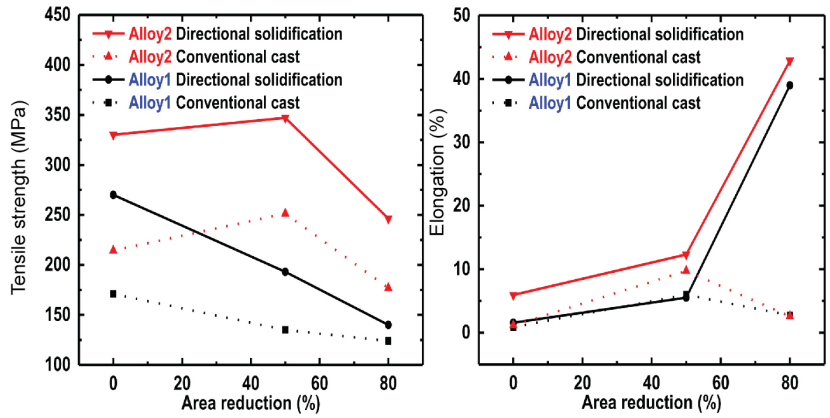

Fig. 13. Tensile properties of $\mathrm{Zn}-\mathrm{Al}$ alloys: (a) tensile strength and (b) elongation.

합금에 $\mathrm{Cu}$ 를 첨가하고, 일방향 응고 그리고 $80 \%$ 의 단면적 감소율로 상온 인발을 행했을 경우, 높은 강도와 연성을 가진 공정합금을 제조할 수 있었다.

\section{4. 고 찰}

공정조성의 $\mathrm{Zn}-\mathrm{Al}$ 합금에서, $\mathrm{Cu}$ 첨가 그리고 일방향 응고 유무에 따른 인장강도 및 연신율의 변화를 상온 인발율에 따 라 나타낸 결과를 그림 13 에 나타내었다. 우선 일반주조법에 의해 제조된 합금보다 일방향 응고된 합금에서 $\mathrm{Cu}$ 의 첨가유 무에 관계없이 모든 인발 조건에서 높은 인장강도와 연성을 가지는 것이 나타났다. 그리고 각 합금을 일방향 응고 후 인 발가공한 결과 연성이 증가한 것이 나타났다. 이는 가공열발 생 또는 응력유기 상분해[29]에 의한 국부적인 회복 또는 재 결정화 효과로 사료된다. 즉 $\mathrm{Zn}-5 \mathrm{wt} \% \mathrm{Al}$ 합금은 그림 2의 상태도에 나타낸 바와 같이 $381{ }^{\circ} \mathrm{C}$ 에서 용융이 일어난다. 이 는 용융점 대비 상온비 $\left(\mathrm{T} / \mathrm{T}_{\mathrm{m}}, \mathrm{K}\right)$ 가 0.456 로써, 상온이 비교적 고온이어서 회복, 재결정화가 발생할 수 있다는 의미가 된다. 그리고 가공시 발생하는 열도 가공경화를 해소하는 데 영향 을 미쳤을 것으로 판단된다. 그런데, $\mathrm{Cu}$ 를 첨가한 시편에서 $50 \%$ 단면적 감소율(true strain, $\eta=0.73$ )의 인발이 진행되었 을 때, 연신율과 함께 인장강도 역시 증가하는 경향을 나타내 었다(그림 $12(\mathrm{~d}))$. 이러한 결과는 연성의 증가가 강도의 감소 를 야기한다는 일반적인 금속의 매우 상반된다. 낮은 용융점 에 의한 상온에서의 동적 재결정화 및 응력유기 상분해는 일 반적으로 강도상승을 야기할 수 없는데, 본 실험의 결과는 이 와 대비되는 결과를 나타내었다. 이는 $\mathrm{Cu}$ 첨가에 의한 고용 강화 즉 $\mathrm{Zn}$ 또는 $\mathrm{Al}$ rich 상에 고용된 $\mathrm{Cu}$ 가 가공 시 생성되는 전위의 이동을 효과적으로 억제시켰기 때문으로 해석된다. 그러므로, $50 \%$ 의 단면적 감소율로 가공된 시편의 경우는 가 


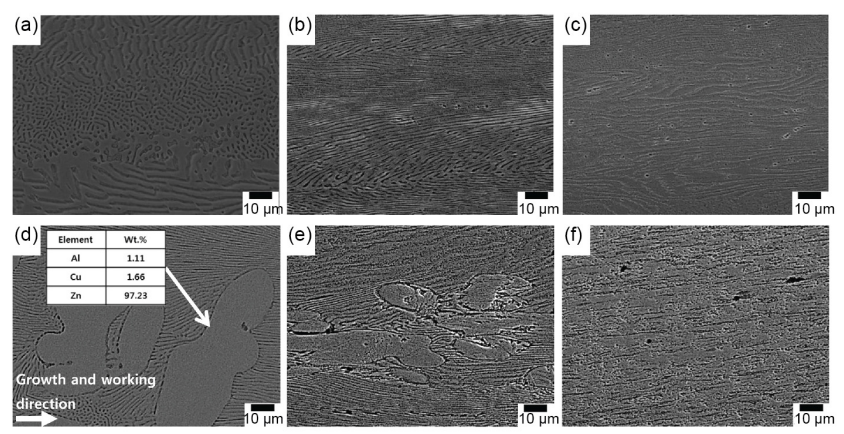

Fig. 14. SEM images of $\mathrm{Zn}-\mathrm{Al}$ alloy alter directional solidification: (a-c): alloy 1 (d-f): alloy 2, (a,d): as-cast, (b,e): 50\% drawn, and (c,f): $80 \%$ drawn.
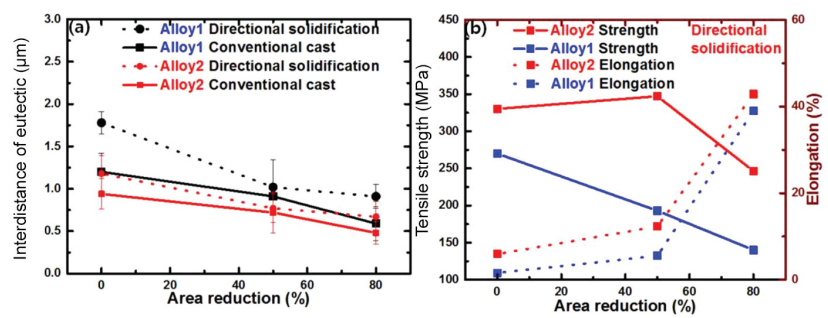

Fig. 15. Change of (a) interdistance and (b) tensile strength of $\mathrm{Zn}-\mathrm{Al}$ alloys with increasing area reduction during drawing.

공경화 효과가 응력유기 상분해 또는 동적 재결정화에 의한 강도감소효과에 비해 지배적으로 나타난 것으로 생각된다. $80 \%$ 의 단면적 감소율로 가공된 일방향응고 시편에서는 응 력유기 상분해 또는 동적 재결정화가 지배적으로 나타나 강 도의 감소와 연신율 증가를 야기하는 것으로 사료된다. 그러 나 일반 주조 시편에서 $80 \%$ 인발 후 강도와 연성이 함께 감 소한 이유는 일방향 응고 시편에 비해 응고초기 무질서한 결 정립계가 생성되고 입계의 크기 또한 균질하지 못하여 인장 시험 시 국부적인 응력 집중이 야기되어 크랙을 용이하게 형 성시키기 때문으로 사료된다. 따라서, alloy 1,2 에서 $80 \%$ 단 면감소율로 인발된 시편의 강도와 연신율을 감소된 것으로 판단된다.

강도 및 연성 등의 기계적 성질에 미치는 $\mathrm{Cu}$ 첨가 이외에 일방향 응고의 효과를 관찰하기 위하여 각 합금의 인발실험 후 길이방향의 미세조직을 $\mathrm{SEM}$ 으로 관찰하였고 그 결과를 그림 14에 나타내었다. $\mathrm{Cu}$ 첨가에 의해 생성된 초정상은

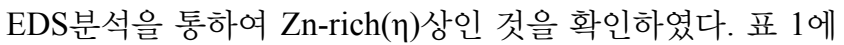
나타낸 바와 같이 본 합금에서 $\mathrm{Cu}$ 첨가는 $\mathrm{Al}$ 의 상대적인 분 율이 증가 하였다. 그럴 경우, $\mathrm{Zn}$ 의 상대적인 함량이 줄기 때 문에 그림 2의 상태도에서 아공정 조성에 합금 조성이 될 수

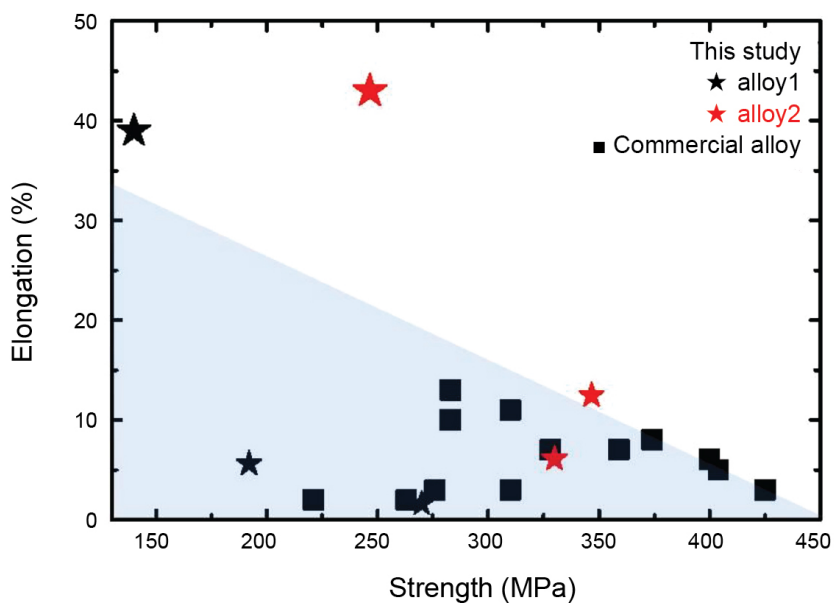

Fig. 16. Strength and ductility relation of drawn $\mathrm{Zn}-\mathrm{Al}$ alloy at room temperature.

도 있으나 본 연구에서는 초정상이 Zn-rich(ๆ)상이 형성되었 다. 이는 그림 5 의 $\mathrm{DSC}$ 분석에서 $\mathrm{Cu}$ 첨가 합금에서 무첨가합 금 $(\mathrm{Zn}-\mathrm{Al})$ 보다 초정이 먼저 생기며 또한 양이 더 많이 형성됨 을 보여주어 $\mathrm{Cu}$ 의 첨가는 $\mathrm{Al}-\mathrm{Zn}$ 상태도(그림 2)에서 $\eta$ 상의 영역이 확장될 것으로 예상된다.

각 합금에서 $\mathrm{Cu}$ 첨가유무 그리고 인발가공율 증가에 따른 층상구조간의 간격변화를 그림 $15(\mathrm{a})$ 에 나타내었다. 인발가 공률이 증가할수록 모든 합금의 층상간격은 감소하는 경향 을 보였는데, 층상구조의 층상간격의 감소는 제 2 상의 간격 이 전위의 이동을 방해하는 것에 효과적이므로 인장강도 증 가에도 효과적으로 영향을 준 것으로 판단된다 [23].

공정 $\mathrm{Zn}-\mathrm{Al}$ 합금에 $\mathrm{Cu}$ 를 첨가했을 경우, 합금 내의 $\mathrm{Cu}$ 의 고용, 그리고 $\mathrm{Al}$ rich 상의 층상간격 감소 그리고 초정의 생성 으로 강도를 증가시켰을 것으로 사료된다. 또한 일방향 응고 는 층상구조를 길이방향으로 배열시켜, 응력유기 상변화 또 는 동적 재결정화를 용이하게 발생시킨 것으로 사료된다. 즉 상온가공 시 연성이 증가되는 $\mathrm{Zn}-\mathrm{Al}$ 저융점 합금에서 $\mathrm{Cu}$ 를 첨가하고 일방향 응고를 시행한 결과, 연성증가를 유지하고 강도를 향상시킬 수 있었다. 이상의 결과를 종합하여, 그림 1 에 나타낸 상용 $\mathrm{Zn}$ 합금의 결과들과 같이 본 연구의 결과를 그림 16 에 나타내었다. 그 결과, $\mathrm{Cu}$ 가 첨가된 공정조성의 $\mathrm{Zn}-\mathrm{Al}$ 합금을 일방향 응고시킨 후 상온 인발 가공 하였을 때 (그림 16 의 붉은색 별표), 강도와 연성이 우수한 합금을 제조 할 수 있었다. 


\section{5. 결 론}

본 연구는 $\mathrm{Zn}-5 \mathrm{wt} \% \mathrm{Al}$ 합금의 공정조성을 선택하고 추가 적으로 이 조성에 $\mathrm{Zn}$ 의 함량을 줄이고 $2 \mathrm{wt} \%$ 의 $\mathrm{Cu}$ 를 첨가한 후, 일방향 응고를 통해 결정립을 한 방향으로 정렬시켰다. 또한 상온 인발을 통해 공정조직을 일방향으로 배열하였고, 제조된 시편으로 미세조직과 기계적 특성 관계를 분석한 결 과, 결론은 다음과 같다.

1. $\mathrm{Zn}-\mathrm{Al}$ 합금에 $\mathrm{Zn}$ 을 치환하여 $\mathrm{Cu}$ 를 첨가할 경우, $\mathrm{Al}-\mathrm{rich}$ 초정이 생성되지 않고 $\mathrm{Zn}$-rich 초정이 생성되었다.

2. $\mathrm{Zn}-\mathrm{Al}$ 합금에서 $\mathrm{Cu}$ 첨가의 유무에 상관없이 일방향 응 고후 결정립 방향이 응고진행방향으로 배열하였다.

3. $\mathrm{Zn}-\mathrm{Al}$ 합금을 상온인발하였을 경우, $\mathrm{Cu}$ 첨가유무와 상 관없이, 공정조직내의 층상구조는 인발방향으로 배열하였 고, 인발시, 층상구조간 간격은 감소하였다.

4. $2 \mathrm{wt} \% \mathrm{Cu}$ 가 첨가된 $\mathrm{Zn}-5 \mathrm{wt} \% \mathrm{Al}$ 합금을 일방향응고 후, 상온 인발을 통하여 단면적 감소율 $80 \%$ 로 가공했을 경 우, 인장강도 $246 \mathrm{MPa}$, 연성 $43 \%$ 의 결과를 나타내었다.

\section{ACKNOWLEDGEMENT}

This work was supported principally by Global Frontier R\&D Program (2013M3A6B1078874) on Global Frontier Hybrid Interface Materials R\&D Center funded by the Ministry of Science, ICT and Future Planning and the National Research Foundation of Korea (NRF) grant funded by the Korea government (MSIP) [No. 2011-0030058].

\section{REFERENCES}

1. Z. Liu, D. Qiu, F. Wang, J. A. Taylor, and M. Zhang, Metall. Mater. Trans. A 47A, 830 (2016).

2. Z. Liu, R. Li, R. Jiang, X. Li, and M. Zhang, J. Alloy. Compd. 687, 885 (2016).

3. K. Berent, J. Pstrus, and T. Gancarz, J. Mater. Eng. Perform. 25, 3375 (2016).

4. H. Joh, S. Z. Han, J. H. Ahn, J. Lee, Y. G. Son, and K. H. Kim, Korean J. Mater. Res. 25, 202 (2015).

5. K. M. Lim, I. M. Park, S. S. Shin, G. Y. Yeom, and H. J. Son, Korean J. Met. Mater. 53, 627 (2015).
6. J. Kubasek, D. Vojtech, I. Pospisilova, A. Michalcova, and J. Maixner, Int. J. Min. Met. Mater. 23, 1167 (2016).

7. W. K. Krajewski, J. Buras, P. K. Krajewski, A. L. Greer, P. Schumacher, and K. Haberl, IOP Conf. Ser. Mater. Sci. Eng. 143, 1 (2016).

8. M. Demirtas, G. Purcek, H. Yanar, Z. J. Zhang, and Z. F. Zhang, J. Alloy. Compd. 663, 775 (2016).

9. R. Haghayeghi, E. Ezzatneshan, and H. Bahai, Met. Mater. Int. 21, 109 (2015).

10. G. Chen, Q. Chen, B. Wang, and Z. Du, Met. Mater. Int. 21, 897 (2015).

11. M. K. Yu, O. Y. Kwon, T. W. Park, Y. Y. Lee, and S. H. Hong, Korean J. Met. Mater. 53, 844 (2015).

12. S. Sandlobes, Z. Wu, K. G. Pradeep, and S. Korte-Kerzel, Mat. Lett. 175, 27 (2016).

13. H-Y. Li, Y. Zhou, A. Cui, Y. Zheng, Z-Y. Huang, H-X. Zhai, and S-B. Li, Int. J. Appl. Ceram. Technol. 13, 636 (2016).

14. M. Demirtas, G. Purcek, H. Yanar, Z. J. Zhang, and Z. F. Zhang, Mater. Sci. Eng. A. 644, 17 (2015).

15. H. Kaya, U. Boyuk, S. Engin, E. Cadirli, and N. Marasli, J. Electron. Mater. 39, 303 (2010).

16. ASTM (American Society for Testing and Materials) B 86-09.

17. C. A. Parker, Atlas of Stress-Strain Curves 2nd ed., pp.1-19, ASM Int., Ohio (2002).

18. S. Z. Han, K. H. Kim, J. Kang, H. Joh, S. M. Kim, J. H. Ahn, J. Lee, S. H. Lim, and B. Han, Sci. Rep. 5, 17364 (2015).

19. S. Z. Han, H. Joh, J. H. Ahn, J. Lee, S. M. Kim, S. H. Lim, and Y. G. Son, J. Alloy. Compd. 622, 384 (2015).

20. H. Baker, ASM Metals Handbook, Vol. 3, p. 56, ASM Int., Ohio (1992).

21. R. Li, S. Zhang, H. Kang, Z. Chen, F. Yang, W. Wang, C. Zou, T. Li, and T. Wang, J. Alloy. Compd. 639, 592 (2017).

22. S. Tagashira, K. Sakai, T. Furuhara, and T. Maki, ISIJ. Int. 40, 1149 (2000).

23. H. Kaya, M. Gunduz, E. Cadirli, and O. Uzun, J. Mater. Sci. 39, 6571 (2004).

24. S. Z. Han, S. H. Lim, S. Kim, J. Lee, M. Goto, H. G. Kim, B. Han, and K. H. Kim, Sci. Rep. 6, 30907 (2016).

25. S. Z. Han, J. Lee, M. Goto, S. H. Lim, J. H. Ahn, S. Kim, and K. Kim, Phil. Mag. Lett. 96, 196 (2016).

26. J. S. Lee, J. H. Gu, H. M. Jung, E. H. Kim, Y. G. Jung, and J. H. Lee, Mater. Today Proc. 1, 3 (2014).

27. B. Zhang, X. Li, T. Wang, and Z. Liu, Mater. Sci. Eng. A 674, 242 (2016).

28. H. Kaya and A. Aker, J. Alloy. Compd. 694, 145 (2017).

29. B. Straumal, R. Valiev, O. Kogtenkova, P. Zieba, T. Czeppe, E. Bielanska, and M. Faryna, Acta Mater. 56, 6123 (2008). 